\title{
Interactive effects of plant growth regulators and explants on direct shoot regeneration of Viola odorata
}

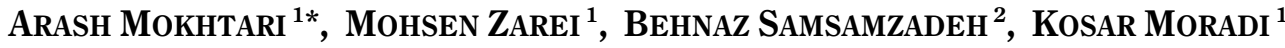 \\ ${ }^{1}$ Department of Plant Tissue Culture, Branch of Central Region of Iran, \\ Agricultural Biotechnology Research Institute of Iran (ABRII), Isfahan, Najafabad, Iran \\ ${ }^{2}$ Department of Agricultural Biotechnology, Payam Noor University of Isfahan, Isfahan, Iran
}

\begin{abstract}
The aim of the study was to develop a protocol for in vitro shoot regeneration based on a solid Murashige and Skoog (MS) basal medium supplemented with various concentrations of plant growth regulators (PGRs) like Indole-3-butyric acid (IBA), kinetin (KIN) or benzylaminopurine (BAP) using leaf, petiole, root, and crown disk segments of a valuable medicinal plant Viola odorata. The best percentage of direct shoot regeneration (67.50\%) and the maximum number of micro-shoots (9.50) were obtained with crown explants on MS medium containing IBA $\left(0.5 \mathrm{mg} \cdot 1^{-1}\right)$ combined with BAP $\left(3 \mathrm{or} 4 \mathrm{mg} \cdot 1^{-1}\right)$. The best elongation $(5.25 \mathrm{~cm})$ of micro-shoots was observed in crown explants on a medium containing $1 \mathrm{mg} \cdot \mathrm{l}^{-1}$ gibberellic acid (GA3) followed by GA3 at $0.5 \mathrm{mg} \cdot \mathrm{l}^{-1}$ and similar explants. Irrespective of the concentrations of GA3, the minimum length of shoots was observed in leaf explants. A half-strength MS medium containing activated charcoal and supplemented with $1.5 \mathrm{mg} \cdot \mathrm{l}^{-1} \mathrm{IBA}$ resulted in the best rooting (78\%) of elongated shoots. All acclimatized plantlets survived and showed a normal growth. The study reports a simple and applicable protocol for micropropagation of $V$. odorata through direct organogenesis.
\end{abstract}

Keywords: crown explants, direct regeneration, GA3, Viola odorata

\section{Introduction}

Sweet violet (Viola odorata L.) is an evergreen perennial medicinal-ornamental plant belonging to the family Violaceae (Kaloo et al. 2012; Mokhtari, 2016). The plant has a strong folk reputation in the treatment of cancer. Viola has been investigated for cytotoxicity and reported as a pharmacological tool serving as antitumor agents (Lindholm et al. 2002; Mokhtari 2016; Gustafson 2004; Ireland et al. 2006; Ebrahimzadeh et al. 2010). Viola also contains salicylic acid, which is used to produce aspirin, and is therefore effective in treating headaches, migraines, and insomnia. Sweet violet is traditionally propagated by a division of rhizomatous disks, but for large-scale cultivation, the seeds are preferred (Mokhtari 2016). However, because of its seed dormancy the germination rate of this medicinal plant is low (Lord 1983; Mokhtari et al. 2015); its population is decreasing at an alarming rate. Also, different species of Violagenus are known to hybridize very freely in nature at intra and inter-specific levels. Thus, identification and taxonomic separation of the members of this genus will be difficult (Kaloo et al. 2012). Recently, in plant biotechnology, in vitro culture techniques have become more frequently used offering a viable tool for mass multiplication and germplasm conservation of valuable and endangered medicinal plants (Ajithkumar and Seeni 1998; Tiwari et al. 2000; Mokhtari 2016). In vitro culture studies include aspects such as direct organogenesis. The ability of individual cells to develop into whole plants, known as totipotency, has formed the basis for regeneration and propagation of selected genotypes through tissue cultures. Micropropagation through direct organogenesis that lacks the callus phase has the advantage of producing plants that are highly identical in their vegetative characteristics with the mother plant (Hussain et al. 1995; Bekheet and Saker 1998; Al-Khateeb 2008). There

\footnotetext{
*Corresponding author: Department of Plant Tissue Culture, Branch of Central Region of Iran, Agricultural Biotechnology Research Institute of Iran (ABRII), Isfahan, Najafabad, Iran, P.O. Box 85135-487; e-mail: rshmokhtari@yahoo.com
} 
is some information on direct organogenesis of V. odorata; however, it is confined to different explants or plant growth regulators (PGRs) (Kaloo et al. 2012). To our knowledge, the presented work is the first to report on direct shoot regeneration of $V$. odorata using leaves, petiole, root, and crown disk explants. The aim of the study was to investigate the effects of all possible combinations of PGRs such as KIN (kinetin), BAP (benzylaminopurine), and IBA (Indole-3-butyric acid) to reach an efficient direct shoot regeneration system for clonal propagation of $V$. odorata that could be used to obtain phytomedicine stocks of elite plants.

\section{Materials and methods}

\section{Explants preparation}

Seeds of sweet violet were collected from the Research Center for Agriculture and Natural Resources, Isfahan, Iran, during 2012-2013 and were then surface sterilized according to Barekat et al. (2013) in the following manner: a) washing ( 5 times) with sterile distilled water and 1 drop of Tween-20; b) immersing in 70\% ethanol for $1 \mathrm{~min}$, followed by washing (3-4 times) with sterile distilled water to remove residual ethanol; c) soaking in $1 \%$ sodium hypochlorite $(\mathrm{NaOCl})$ and 1 drop of Tween-20 for 15 min and finally rinsing with sterile distilled water (4 times) under a laminar flow cabinet.

\section{Direct adventitious shoot regeneration from explants isolated from seedlings}

The embryos of disinfected seeds were prepared and sown on the 1/4 Murashige and Skoog (MS) medium as previously described (Barekat et al. 2013). The embryos were developed into seedlings, and the explants of leaf $(0.5 \times 0.5 \mathrm{~cm})$, petiole $(1 \mathrm{~cm})$, root $(1 \mathrm{~cm})$, and crown disk (bearing 1 lateral bud) were prepared from well-developed in vitro derived seedlings. Four of each explants were horizontally cultured on Petri plates containing $25 \mathrm{ml}$ of regeneration media. A solid MS basal medium was supplemented with various concentrations of IBA $\left(0,0.25\right.$, and $\left.0.5 \mathrm{mg} \cdot 1^{-1}\right)$, KIN $\left(0,0.05\right.$, and $\left.0.1 \mathrm{mg} \cdot 1^{-1}\right)$, and/or $\operatorname{BAP}\left(0,1,2,3\right.$, and $\left.4 \mathrm{mg} \cdot 1^{-1}\right)$. The cultured Petri plates were sealed using a parafilm and incubated at $24^{\circ} \mathrm{C}$ in $16 \mathrm{~h}$ light: $8 \mathrm{~h}$ dark photoperiod (provided by cool-white fluorescent light, irradiance $50 \mu \mathrm{mol} \mathrm{m}^{-2} \mathrm{~s}^{-1}$ ) in a growth chamber for 4 weeks. In this step multiple shoot formation does not occur, thus only the frequency (\%) of explant developing shoots was calculated.

\section{Shoot multiplication from cultured explants}

The explants including developed micro-shoots cultured on shoot regeneration media were selected; their elongated micro-shoots were carefully removed and then sub-cultured in the same media for shoot multiplication and were kept under the same conditions as mentioned above. After another 4 weeks, mean numbers of shoots per explants were calculated.

\section{Elongation of derived micro-shoots}

The solid-basal MS medium fortified with gibberellic acid (GA3) at $0,0.5$, and $1 \mathrm{mg} \cdot \mathrm{l}^{-1}$ was designated for the elongation of individual micro-shoots. After the 3-week incubation under the same conditions, the average length of shoots was recorded.

\section{Root induction of elongated shoots}

Elongated shoots were transferred onto a solidifiedbasal MS medium in half of the strength containing $0.4 \%$ activated charcoal and four concentrations of IBA $(0,0.5$, 1 , and $1.5 \mathrm{mg} \cdot 1^{-1}$ ), in order to investigate the rhizogenesis. After a 2-week incubation under the same conditions as those adjusted in the previous stages of the experiment, the frequency (\%) of explants developing roots was calculated.

\section{Acclimatization of regenerated plants}

Regenerated plants with well-developed root systems were carefully taken out from the culture bottle, washed free of agar, and then transferred into poly pots containing peat + cocopeat + perlite $(2: 1: 1)$. The pots were covered with transparent plastic bags under controlled condition in a greenhouse at $22 \pm 2^{\circ} \mathrm{C}$ and $50-60 \%$ relative humidity and irrigated regularly.

\section{Experimental design and statistical analysis}

All the experiments were set up in a factorial completely randomized design (FCRD). Four replicates per treatments with 4 explants for each replicate (culture vessels) were used. The obtained data were subjected to ANOVA, then analyzed by SAS software package Ver. 9.2. When the ANOVA indicated statistical significance, means were compared using the Least Significant Difference test at $5 \%$ and $1 \%$ probability level to distinguish differences between treatments. 
Table 1. The interaction effect of PGRs and explants on shoot regeneration and shoot number of in vitro derived plantlets of $V$. odorata

\begin{tabular}{|c|c|c|c|}
\hline $\begin{array}{l}\text { Plant growth regulators } \\
\qquad\left[\mathrm{mg} \cdot 1^{-1}\right]\end{array}$ & Explants & $\begin{array}{c}\text { Regeneration } \\
{[\%]}\end{array}$ & $\begin{array}{l}\text { Shoot } \\
\text { number }\end{array}$ \\
\hline $\operatorname{BAP}(2)+\operatorname{KIN}(0.05)+\operatorname{IBA}(0.25)$ & leaf & $36.25 \mathrm{de}$ & $1.00 \mathrm{~cd}$ \\
\hline $\operatorname{BAP}(4)+\mathrm{KIN}(0.05)+\operatorname{IBA}(0.25)$ & $\begin{array}{l}\text { crown } \\
\text { petiole }\end{array}$ & $\begin{array}{l}42.50 \mathrm{~cd} \\
36.25 \mathrm{de}\end{array}$ & $\begin{array}{c}0.00 \mathrm{~d} \\
1.00 \mathrm{~cd}\end{array}$ \\
\hline $\mathrm{BAP}(2)+\mathrm{KIN}(0.05)+\operatorname{IBA}(0)$ & crown & $36.25 \mathrm{de}$ & $0.00 \mathrm{~d}$ \\
\hline $\mathrm{BAP}(2)+\mathrm{KIN}(0.05)+\operatorname{IBA}(0)$ & crown & $36.25 \mathrm{de}$ & $0.50 \mathrm{~d}$ \\
\hline $\mathrm{BAP}(1)+\mathrm{KIN}(0.05)+\mathrm{IBA}(0.5)$ & petiole & $36.25 \mathrm{de}$ & $1.00 \mathrm{~cd}$ \\
\hline $\mathrm{BAP}(3)+\mathrm{KIN}(0.05)+\mathrm{IBA}(0.5)$ & $\begin{array}{l}\text { crown } \\
\text { petiole } \\
\text { leaf }\end{array}$ & $\begin{array}{l}42.50 \mathrm{~cd} \\
42.50 \mathrm{~cd} \\
42.50 \mathrm{~cd}\end{array}$ & $\begin{array}{l}3.00 \mathrm{bc} \\
1.25 \mathrm{~cd} \\
1.00 \mathrm{~cd}\end{array}$ \\
\hline $\mathrm{BAP}(4)+\mathrm{KIN}(0.05)+\mathrm{IBA}(0.5)$ & petiole & $42.50 \mathrm{~cd}$ & $1.25 \mathrm{~cd}$ \\
\hline $\operatorname{BAP}(1)+\mathrm{KIN}(0)+\operatorname{IBA}(0.5)$ & petiole & $8.33 \mathrm{~d}$ & $1.25 \mathrm{~cd}$ \\
\hline $\operatorname{BAP}(3)+\mathrm{KIN}(0)+\operatorname{IBA}(0.5)$ & $\begin{array}{l}\text { crown } \\
\text { petiole }\end{array}$ & $\begin{array}{l}63.33 \mathrm{a} \\
42.50 \mathrm{~cd}\end{array}$ & $\begin{array}{l}9.50 \mathrm{a} \\
1.50 \mathrm{~cd}\end{array}$ \\
\hline $\mathrm{BAP}(4)+\mathrm{KIN}(0)+\operatorname{IBA}(0.5)$ & $\begin{array}{l}\text { crown } \\
\text { petiole }\end{array}$ & $\begin{array}{l}67.50 \mathrm{a} \\
42.50 \mathrm{~cd}\end{array}$ & $\begin{array}{l}8.00 \mathrm{a} \\
1.75 \mathrm{~cd} \\
\end{array}$ \\
\hline $\mathrm{BAP}(4)+\mathrm{KIN}(0)+\operatorname{IBA}(0.5)$ & leaf & $42.50 \mathrm{~cd}$ & $1.75 \mathrm{~cd}$ \\
\hline $\mathrm{BAP}(1)+\mathrm{KIN}(0.1)+\mathrm{IBA}(0.5)$ & $\begin{array}{c}\text { petiole } \\
\text { leaf }\end{array}$ & $\begin{array}{c}36.25 \mathrm{de} \\
0.00 \mathrm{f}\end{array}$ & $\begin{array}{l}0.50 \mathrm{~d} \\
0.00 \mathrm{~d}\end{array}$ \\
\hline $\operatorname{BAP}(4)+\mathrm{KIN}(0.1)+\operatorname{IBA}(0.5)$ & crown & $6.25 \mathrm{de}$ & $0.75 \mathrm{~cd}$ \\
\hline $\mathrm{BAP}(3)+\mathrm{KIN}(0.1)+\operatorname{IBA}(0)$ & $\begin{array}{l}\text { crown } \\
\text { petiole }\end{array}$ & $\begin{array}{l}42.50 \mathrm{~cd} \\
36.25 \mathrm{de}\end{array}$ & $\begin{array}{l}2.50 \mathrm{c} \\
0.50 \mathrm{~d}\end{array}$ \\
\hline $\mathrm{BAP}(3)+\mathrm{KIN}(0.1)+\operatorname{IBA}(0)$ & leaf & $36.25 \mathrm{de}$ & $0.00 \mathrm{~d}$ \\
\hline $\operatorname{BAP}(0)+\mathrm{KIN}(0)+\operatorname{IBA}(0.25)$ & crown & $36.25 \mathrm{de}$ & $2.00 \mathrm{~cd}$ \\
\hline $\mathrm{BAP}(1)+\mathrm{KIN}(0)+\mathrm{IBA}(0.25)$ & $\begin{array}{c}\text { crown } \\
\text { petiole } \\
\text { leaf }\end{array}$ & $\begin{array}{l}42.50 \mathrm{~cd} \\
36.25 \mathrm{de} \\
42.50 \mathrm{~cd}\end{array}$ & $\begin{array}{l}4.50 \mathrm{~b} \\
0.75 \mathrm{~cd} \\
1.50 \mathrm{~cd}\end{array}$ \\
\hline $\mathrm{BAP}(2)+\mathrm{KIN}(0)+\operatorname{IBA}(0.25)$ & $\begin{array}{c}\text { crown } \\
\text { petiole } \\
\text { leaf }\end{array}$ & $\begin{array}{c}55.00 \mathrm{~b} \\
42.50 \mathrm{~cd} \\
42.50 \mathrm{~cd}\end{array}$ & $\begin{array}{l}3.00 \mathrm{bc} \\
1.00 \mathrm{~cd} \\
1.25 \mathrm{~cd}\end{array}$ \\
\hline $\mathrm{BAP}(3)+\mathrm{KIN}(0)+\operatorname{IBA}(0.25)$ & $\begin{array}{c}\text { crown } \\
\text { petiole } \\
\text { leaf }\end{array}$ & $\begin{array}{l}48.75 \mathrm{bc} \\
42.50 \mathrm{~cd} \\
42.50 \mathrm{~cd}\end{array}$ & $\begin{array}{l}4.50 \mathrm{~b} \\
0.75 \mathrm{~cd} \\
1.00 \mathrm{~cd}\end{array}$ \\
\hline $\mathrm{BAP}(4)+\mathrm{KIN}(0)+\mathrm{IBA}(0.25)$ & $\begin{array}{l}\text { crown } \\
\text { petiole } \\
\text { leaf }\end{array}$ & $\begin{array}{l}48.75 \mathrm{bc} \\
42.50 \mathrm{~cd} \\
42.50 \mathrm{~cd}\end{array}$ & $\begin{array}{l}8.50 \mathrm{a} \\
1.25 \mathrm{~cd} \\
1.25 \mathrm{~cd}\end{array}$ \\
\hline
\end{tabular}

Means followed by different letters in columns are significantly different at $P=0.05$ according to the LSD test

\section{Results}

\section{Interactive effect of PGRs and explants type on direct shoot regeneration}

Direct shoot formation was observed on crown, petiole, and leaf explants after a 4 -week culture incubation. The percentage of shoot regeneration ranged from
$0.00 \%$ to $67.50 \%$. There was a significant difference between various concentrations of PGRs and explant types in the percentage of regeneration and number of shoots per explant. First, it must be mentioned that from among 45 possible combinations of PGRs used, those that produced no results on explants were not listed in 


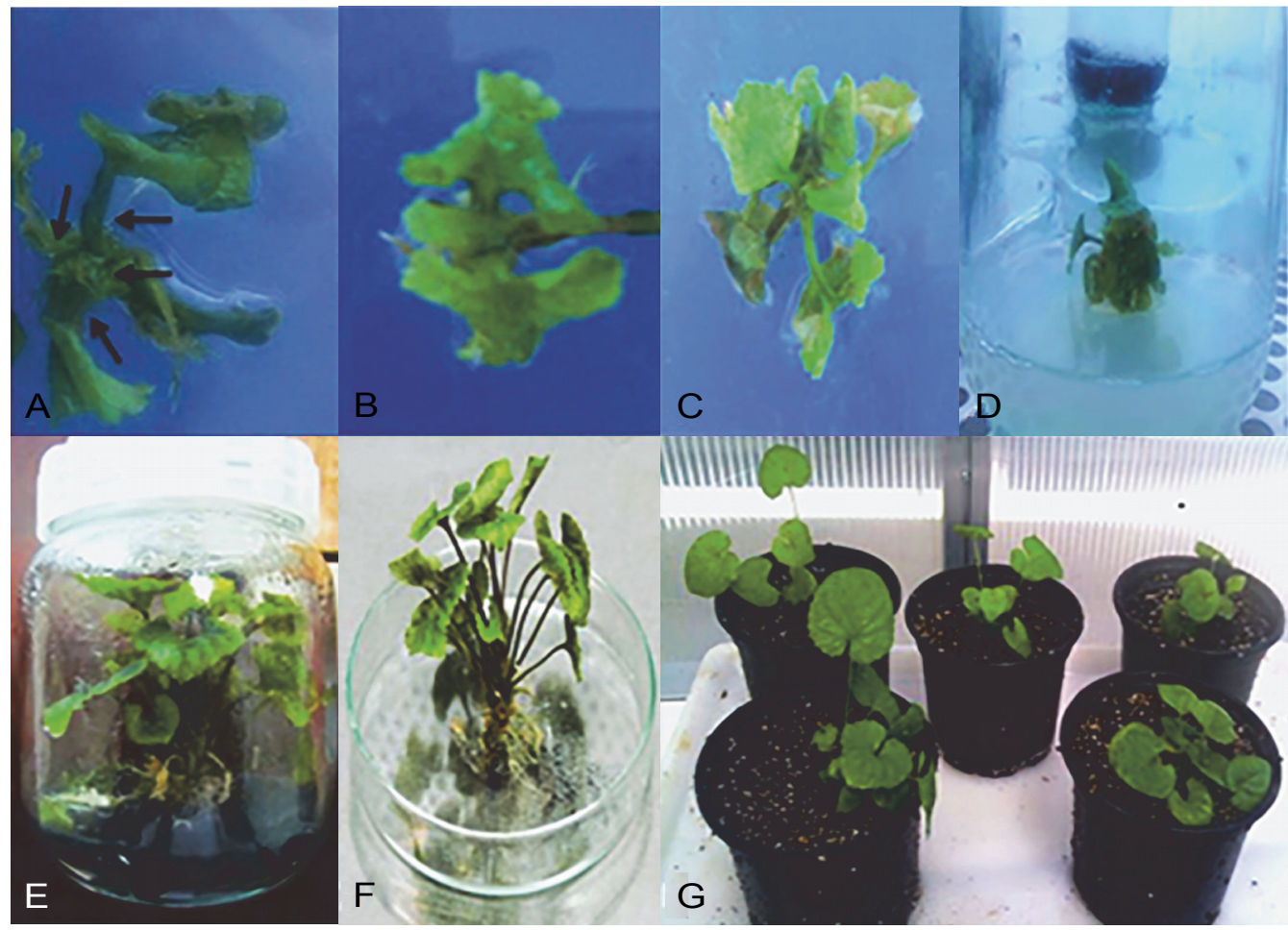

Fig. 1. Multiple shoot regeneration from crown disk explants in MS medium containing $\left(4 \mathrm{mg} \cdot \mathrm{l}^{-1}\right) \mathrm{BAP}+\left(0.5 \mathrm{mg} \cdot \mathrm{1}^{-1}\right) \mathrm{IBA}(\mathrm{A}-\mathrm{C})$; explants in the elongation medium (D); root induction medium (E); rooted plantlet (F); normal growth of plants in greenhouse $(\mathrm{G})$

Table 1. Also, the response of root explants was not observed in none of the applied PGR combination (data not shown). The best value of regeneration (67.50\%) was obtained with crown explants on MS medium containing BAP $\left(4 \mathrm{mg} \cdot 1^{-1}\right)$ and IBA $\left(0.5 \mathrm{mg} \cdot \mathrm{l}^{-1}\right)$ (Fig. $\left.1 \mathrm{~A}-\mathrm{C}\right)$, but it was not significantly $(P=0.01)$ different from the combination of BAP $\left(3 \mathrm{mg} \cdot 1^{-1}\right)$ and IBA $\left(0.5 \mathrm{mg} \cdot 1^{-1}\right)$.

For multiple shoot formation, explants that showed shoot regeneration were sub-cultured on the same media. Our results showed a significant correlation between the percentage of regeneration and the number of shoots per explants. The number of shoots per explants was significantly increased with increasing the percentage of regeneration. After a 4-week sub-culture, the maximum number of micro-shoots was produced after the application of IBA $\left(0.5 \mathrm{mg} \cdot 1^{-1}\right)$ combined with BAP at 3 or $4 \mathrm{mg} \cdot 1^{-1}$ or IBA $\left(0.25 \mathrm{mg} \cdot 1^{-1}\right)$ and BAP $\left(4 \mathrm{mg} \cdot \mathrm{l}^{-1}\right)$ on crown explants followed by MS medium supplemented with IBA $\left(0.5 \mathrm{mg} \cdot 1^{-1}\right)$ and BAP at 1 or $3 \mathrm{mg} \cdot \mathrm{l}^{-1}$ (Table 1). No micro-shoots were observed in the case of leaf explant on MS medium containing BAP $\left(1 \mathrm{mg} \cdot \mathrm{l}^{-1}\right)$, KIN $\left(0.1 \mathrm{mg} \cdot 1^{-1}\right)$, and IBA $\left(0.5 \mathrm{mg} \cdot 1^{-1}\right)$ (Table 1$)$. Table 1 shows that irrespective of applied PGRs, crown ex- plants exhibited the best responses expressed as a percentage of regeneration and the number of shoots formed.

\section{Effects of GA3 and explant types on shoot elongation from induced shoot}

Based on the results presented in Figure 2, the interactive effect of GA3 levels and explant types significantly influenced the elongation responses of proliferated shoots. The best elongation $(5.25 \mathrm{~cm})$ was observed in crown explants that were transferred into a medium containing GA3 at $1 \mathrm{mg} \cdot 1^{-1}$ followed by GA3 at $0.5 \mathrm{mg} \cdot 1^{-1}$ and similar explants. Irrespective of concentrations of GA3, the minimum lengths of shoots were observed in leaf explants (Fig. 1D and Fig. 2).

\section{The effect of IBA concentration on rooting of elongated shoots}

Although some regenerated micro-shoots were successfully rooted in some media mentioned earlier in this paper, the elongated shoots of all explants were transferred to a root induction medium for further rooting. After the 2-week inoculation, the root formation frequency (\%) was calculated. The percentage of shoots for 


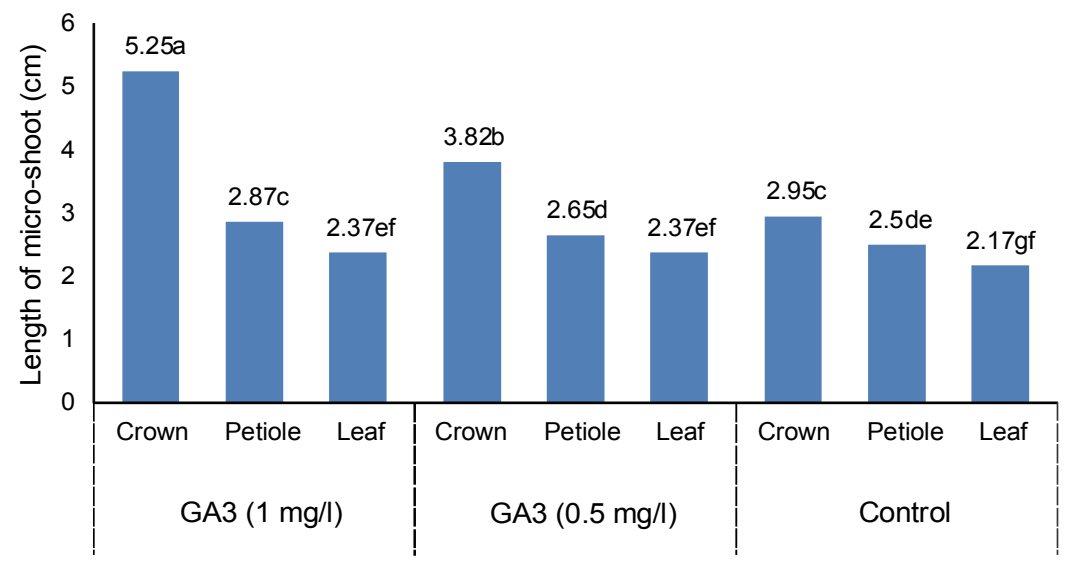

Fig. 2. Explant types and the interactive effects of GA3 on the elongation of micro-shoots of $V$. odorata

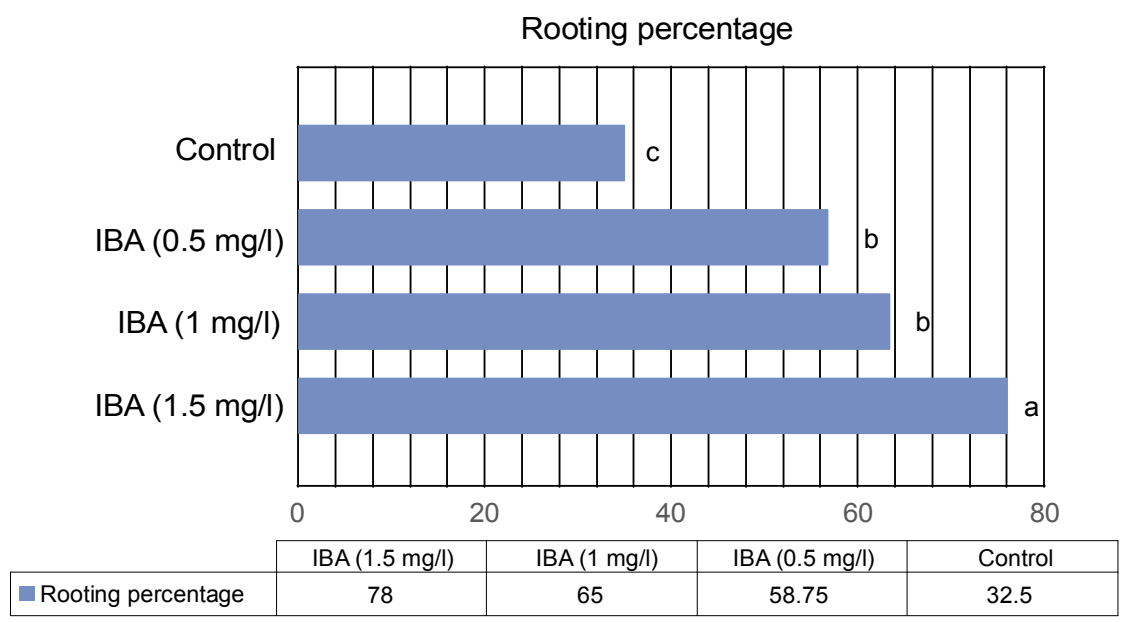

Fig. 3. The effect of various levels of IBA on the rooting of elongated shoots of $V$. odorata

ming roots was significantly $(P=0.01)$ affected by IBA. Satisfactory results were reached in rooting $(32.50-78 \%)$. As the concentration of IBA rose, the rooting frequency increased as well. The best rooting (78\%) was obtained in a half-strength MS medium supplemented with $1.5 \mathrm{mg} \cdot 1^{-1}$ followed by 0.5 or $1 \mathrm{mg} \cdot 1^{-1} \mathrm{IBA}$ (Fig. $1 \mathrm{E}$ and Fig. 1F, Fig. 3). All the acclimatized plantlets survived showing the normal growth (Fig. 1G).

\section{Discussion}

This study reports in vitro plant regeneration of $V$. odorata through direct shoot organogenesis. Our experimental results have shown that the combination of cytokinins and auxins is needed for the best proliferation rates. BAP was superior than KIN between the two cytokinins that were used. With BAP and IBA combinations, the maximum percentage of regeneration and the highest number of shoots were grown. In previous ex- periments, in micropropagation of the cadmium hyperaccumulator Viola baoshanensis (Violaceae), the best shoot regeneration efficiency was obtained by incubating a leaflet in a $1 / 2 \mathrm{MS}$ medium supplemented with $2.5 \mu \mathrm{M}$ $\mathrm{BAP}+2.5 \mu \mathrm{M}$ IBA (Li et al. 2010). This observation was supported by Bogaert et al. (2006) who stated that kinetin has a relatively low biological activity in certain bio-assays. Kalyani and Rao (2014) also found that the percentage of response and shoot number per explants were lower at all concentrations of KIN (in comparison with $\mathrm{BAP}$ ) used. The authors reported that the combination of $3.0 \mathrm{mg} \cdot 1^{-1} \mathrm{BAP}$ and $1.0 \mathrm{mg} \cdot \mathrm{l}^{-1}$ IAA showed the best response and produced the maximum number of shoots per explants $(12.3 \pm 0.42)$. This combination was found to be better than any of the other combinations and concentrations analyzed on direct shoot regeneration in tomato leaf explants. Kaloo et al. (2012) showed the influence of auxin (NAA, 1-Naphthaleneacetic acid), 
cytokinins (KIN, BAP), and their combinations on the multiplication of shoot tips and axillary buds in $V$. odorata. When the nodal cuttings were treated with various combinations of NAA, BAP, and KIN, the results were improved with maximum sprouting on $15 \mu \mathrm{M}$ NAA and $10 \mu \mathrm{M}$ BAP in $90 \%$ of cultures. The effect of different concentrations of BAP, kinetin, TDZ (thidiazuron), and Zeatin on direct regeneration of Digitalis lamarckii were reported (Verma et al. 2011). The medium without PGRs (control) and those containing kinetin and Zeatin did not produce any shoots. BAP at 0.5 and $1.0 \mathrm{mg} \cdot 1^{-1}$ was effective for direct shoot organogenesis from leaf explants. Based on this study, IBA at $0.25-0.5 \mathrm{mg} \cdot 1^{-1}$ is favored to shoot proliferation; this confirms reports that the combination of $0.2 \mathrm{mg} \cdot \mathrm{l}^{-1} \mathrm{IBA}$ with BAP is more effective than one with kinetin or Zeatin (Verma et al. 2011).

The regeneration process can be affected by explant types as shown in our results. This is consistent with the previous report where it was shown that the in vitro shoot induction may depend on the type of explants. Such a difference may be caused by different concentrations of endogenous PGRs and metabolism rates (Gray 2004; Haghighat Afshar et al. 2011). In the case of runner tips, the rate of shoot multiplication showed a lower multiplication rate than in the case of axillary buds in $V$. odorata, and it was concluded that the nodal segment explants responded better than runner tips to shoot multiplication (Kaloo et al. 2012).

GA3 can stimulate shoot elongation by inhibiting the action of auxins in meristematic regions (Taiz and Zeiger 1998). Based on the results presented in Figure 2 , shoot elongation was best when treated with GA3 $\left(1 \mathrm{mg} \cdot 1^{-1}\right)$, which is in agreement with Ghanti et al. (2004). The authors reported that the longest shoots occurred on MS medium containing $1 \mathrm{mg} \cdot \cdot^{-1} \mathrm{GA} 3$ followed by 0.5 $\mathrm{mg} \cdot \mathrm{l}^{-1} \mathrm{GA} 3$ in Mentha piperata L. Shoots treated with GA3 to increase the length of shoots during multiplication or before rooting have been reviewed (George and Debergh 2008). The Murashige and Skoog (MS) medium along with gibberellic acid (GA3) at $1 \mathrm{mg} \cdot \mathrm{l}^{-1}$ produced the maximum of shoot elongation in direct and indirect regenerated shoots from epicotyls explants of Withania somnifera L. (Udayakumar et al. 2013).

It is well established that auxins are potent PGRs for rooting (Vuylasteker et al. 1998; Nandagopal and Kumari 2007). According to the results presented based on our experiments, the percentage of rooting was directly pro- portional to the concentration of IBA as the best rooting occurred on 1/2 MS medium containing a higher concentration of IBA $\left(1.5 \mathrm{mg} \cdot \mathrm{l}^{-1}\right)$. These findings are in agreement with the reports available for other medicinal plants, such as Adhato davasica (Azad et al. 1999) and Holo-stemma ada-kodien (Martin 2002). Also, among the three types of auxins used, IBA was the best for root induction while IAA was the least effective for rooting of direct shoot regenerated from the medicinal plant Phellodendron amurense (Azad et al. 2005). In V. baoshanensis (Violaceae), rooting was also reached from almost all regenerated shoots grown on $1 / 2 \mathrm{MS}$ medium, although without PGRs. This may be attributed to the differences in plant species (Li et al. 2010).

\section{Conclusion}

This study reports a simple and applicable protocol for micropropagation of $V$. odorata via direct organogenesis. The response of $V$. odorata micropropagation depends on the explant type and on the PGR treatments. A crown disk segment is the best explant source for the species, and an efficient micro-shoot can be induced on MS medium containing IBA $\left(0.5 \mathrm{mg} \cdot 1^{-1}\right)$ in combination with BAP ( 3 or $\left.4 \mathrm{mg} \cdot 1^{-1}\right)$. Based on our findings, MS medium containing $1 \mathrm{mg} \cdot 1^{-1}$ of GA3 and half-strength MS medium supplemented with $1.5 \mathrm{mg} \cdot 1^{-1} \mathrm{IBA}$ can be recommended for elongation and rhizogenesis.

\section{References}

Ajithkumar D., Seeni S. (1998) Rapid clonal multiplication through in vitro axillary shoot proliferation of Aegle marmelos (L) Corr A Medicinal Tree. Plant Cell Rep. 17: 422426.

Al-Khateeb A. (2008) Comparison effects of sucrose and date palm syrup on somatic embryogenesis of date palm (Phoenix dactylifera L.). Am. J. Biochem. Biotech. 4: 19-23.

Azad M.A.K., Amin M.N., Begum F. (1999) In vitro rapid regeneration of plantlets from cotyledon explant of Adhatoda vasica Nees. Plant Tiss. Cult. 9: 121-126.

Azad M.A.K., Yokota S., Ohkubo T., Andoh Y., Yahara S., Yoshizawa N. (2005) In vitro regeneration of the medicinal woody plant Phellodendron amurense Rupr. Through excised leaves. Plant Cell Tiss. Org. 83: 43-50.

Barekat T., Othroshy M., Samsamzadeh B., Sadrarhami A., Mokhtari A. (2013) A novel approach for breaking seed dormancy and germination in Viola odorata (A medicinal plant). J. Nove. Appl. Sci. 2: 513-516.

Bekheet S.A., Saker M.M. (1998) In vitro propagation of Egyptian Date Palm: II. Direct and indirect shoot proliferation from shoot tip explants of Phoenix dactylifera L. $\mathrm{CV} Z \mathrm{Za}$ - 
ghlool. [In:] Proceedings first international conference on date palm. Ed. Al Ain, UAE: 150-157.

Bogaert I., Van Cauter S., Werbrouck S.P.O., Dolezal K. (2006) New aromatic cytokinins can make the diff erence. [In:] VInternational Symposium on In Vitro Culture and Horticultural Breeding 725, pp. 265-270.

Ebrahimzadeh M.A., Nabavi S.f., Nabavi S.M., Slami B.E. (2010) Antioxidant and free radical scavenging activity of $H$. officinalis $L$. var. angustifolius, $V$. odorata, B. hyrcana and $C$. speciosum. Pak. J. Pharm. Sci. 23: 29-34.

George E.F., Hall M.A., De Klerk G.J. (2008) Micropropagation: uses and methods. [In:] Plant propagation by tissue culture. Netherlands, Springer: 29-64.

Ghanti K.R.B., Venugopal F.T.Z., Jabeen C.P., Rao S. (2004) Rapid regeneration of Mentha piperita L. from shoot tip and nodal eexplants. Indian J. Biotech. 3: 594-598.

Gray W.M. (2004) Hormonal regulation of plant growth and development. PLoS Bio. 2: 1270-1273.

Gustafson K.R., McKee T.C., Bokesch H.R. (2004) Anti-HIV cyclotides. Curr. Protein Pept. Sci. 5: 331-340.

Haghighat Afshar M., Jafarkhani M., Khalighi A., Habashi A., Mohamadi A. (2011) Direct shoot regeneration on three cultivars of rosa hybrid using five explant types and different hormone concentrations. Amer.-Eurasian J. Agric. Environ. Sci. 10: 962-967.

Hussain I.Q. Ahmad M., Quraishi A.Z.R. (1995) Effect of explant source on in vitro regeneration of plants through tissue culture proliferation in (Phoenic dactylifera L.) $\mathrm{cv}$. Fusli. Pak. J. Bot. 27: 101-104.

Ireland D.C., Colgrave M.L., Craik D.G. (2006) A novel suite of cyclotides from Viola odorata: sequence variation and the implications for structure, function and stability. Biochem. J. 400:1-12.

Kaloo A.Z.R., Akhtar Z., Wafai B.A. (2012) Effect of growth regulators on the in vitro multiplication of Viola odorata. Int. J. Med. Plant Res. 4: 187-189.

Kalyani B.G., Rao S. (2014) Effect of hormones on direct shoot regeneration in leaf explants of tomato. Int. J. Res. Biotech. Biochem. 4: 20-22.

Li J.T., Deng D.M., Peng G.T., Deng J.C., Zhang J., Liao B. (2010) Successful micropropagation of the cadmium hyper accumulator Viola baoshanensis (Violaceae). Int. J. Phytoremediation. 12: 160-210.
Lindholm P., Goransson U., Johansson S., Claeson P., Gulibo J., Larsson R., Bohlin L., Backlund A. (2002) Cyclotides a novel type of cytotoxic agents. Mol. Cancer Ther. 1: 365369.

Lord A.M.M. (1983) Comparative Flower Development in the Cleistogamous Species Viola odorata. I. A Growth Rate Study. Amer. J. Bot. 1: 1556-1563.

Martin K.P. (2002) Rapid propagation of Holostemma adakodien Schult., a rare medicinal plant, through axillary bud multiplication and indirect organogenesis. Plant Cell Rep. 21: 112-117.

Mokhtari A. (2016) Medicinal Plants: Sweet violet (Viola odorata), Description, Medicinal uses and Micropropagation. Saarbrucken, Deutschland/Germany: LAP LAMBERT Academic Publishing.

Mokhtari A., Otroshy O., Barekat T. (2015) Plant regeneration through callus induction on medicinal herb Viola odorata role of plant growth regulators and explants. Agricult. Forest. 61: 3-16.

Nandagopal S., Kumari R.B.D. (2007) Effectiveness of auxin induced in vitro root culture in chicory. J. Cen. Europ. Agri. 8: 73-79.

Taiz L., Zeiger E. (1998) Plant Physiology, $2^{\text {nd }}$ ed. Sinauer Associates, Sunderland, MA, USA.

Tiwari K.N., Sharma N.C., Tiwari V., Singh B.D. (2000) Micropropagation of Centella asiatica (L.), a valuable medicinal herb. Plant Cell Tiss. Org. Cult. 63: 179-185.

Udayakumar R., Choi C.W., Kim K.T., Kim S.C., Kasthurirengan S., Mariashibu T.S., Sahaya Rayan J.J., Ganapathi A. (2013) In vitro plant regeneration from epicotyl explant of Withania somnifera (L.) Dunal. J. Med. Plants Res. 7: 43-52.

Verma S.K., Yucesan B.B., Sahin G., Gurel S., Gurel E. (2011) Direct shoot regeneration from leaf explants of Digitalis lamarckii, an endemic medicinal species. Turk. J. Bot. 35: 689-695.

Vuylasteker C., Dewaele S., Rambour S. (1998) Auxin induced lateral root formation in chicory. Ann. Bot. 81: 449-454. 